\title{
Pengaruh Peran PR terhadap Reputasi Perusahaan Operator Selular
}

\author{
Realina, H.H.Daniel Tamburian \\ realina.915160030@stu.ac.id danielt@fikom.untar.ac.id \\ Fakultas Ilmu Komunikasi Universitas Tarumanagara
}

\begin{abstract}
Reputation is something that cannot be seen but can be felt, having a good reputation is the main goal that every company wants to achieve. Therefore, researchers discuss the influence of the role of PR on Telkomsel's corporate reputation. According to Charles J. Fombrun (2016) stated that there are four aspects that create a company's reputation, namely credibility, reliability, trustworthiness, responsibility. (p.48) Whereas the measurement of the role of public relations was adopted from the dimensions proposed by Cutlip (2009, p.45) including communication technicians, expert prescriber, communication facilitators and problem solving facilitators. This research methodology is quantitative by distributing 100 questionnaires to Telkomsel users. From this study, the results of linear regression $Y=6.081$ $+0.808 \mathrm{X}$, and a significance value of 0,000<0.05. States there is a significant influence between the role of PR on Telkomsel's corporate reputation. It can be concluded that the role of $P R$ has a significant influence on Telkomsel's corporate reputation.
\end{abstract}

Keywords: pr role, public relations, reputation

\begin{abstract}
Abstrak
Reputasi merupakan sesuatu yang tidak bisa dilihat namun dapat dirasakan, memiliki reputasi yang baik adalah tujuan utama yang ingin dicapai oleh setiap perusahaan. Oleh sebab itu, peneliti membahas tentang pengaruh peran PR terhadap reputasi perusahaan Telkomsel. Menurut Charles J. Fombrun (2016) mengemukakan bahwa ada empat aspek yang menciptakan reputasi perusahaan yakni credibility, reliability, trustworthiness, responsibility. (p.48) Sedangkan pengukuran peran PR diadopsi dari dimensi yang dikemukakan oleh Cutlip (2009, p.45) antara lain expert prescriber, teknisi komunikasi, fasilitator pemecahan masalah dan fasilitator komunikasi. Metodologi penelitian ini adalah kuantitatif dengan menyebarkan 100 kuesioner kepada pengguna Telkomsel. Dari penelitian ini, diperoleh hasil regresi linier $\mathrm{Y}=6,081+0,808 \mathrm{X}$, serta nilai signifikansi sebesar $0,000<0,05$. Menyatakan terdapat pengaruh signifikan antara peran PR terhadap reputasi perusahaan Telkomsel. Maka dapat disimpulkan peran PR memberikan pengaruh yang signifikan terhadap reputasi perusahaan Telkomsel.
\end{abstract}

Kata Kunci: peran $P R$, public relations, reputasi

\section{Pendahuluan}

Pertumbuhan ekonomi yang pesat membuat perusahaan dari berbagai industri bersaing untuk mendapatkan dan mempertahankan konsumen demi mencapai keuntungan dan keberlangsungan dari sebuah perusahaan. Berbagai cara dilakukan oleh perusahaan-perusahaan di Indonesia untuk meningkatkan reputasi perusahaan. Reputasi dianggap menjadi nilai tinggi yang menjadi tujuan utama dari kegiatan PR karena reputasi yang baik membuat nilai perusahaan menjadi tinggi dan unggul 
dibandingkan kompetitor-kompetitor yang memiliki produk atau jasa dibidang yang serupa.

Perkembangan teknologi ini menjadi tantangan tersendiri bagi perusahaan operator telekomunikasi, dengan kehadiran smartphone perusahaan operator juga terus beradaptasi untuk memenuhi kebutuhan konsumen dalam menunjang aktivitas di dunia maya. Sebelumnya perusahaan operator hanya menyediakan paket SMS dan telepon, Seperti diketahui, pasca layanan telekomunikasi dasar seperti voice dan SMS terpenuhi, maka kebutuhan masyarakat selanjutnya meningkat pada layanan yang berpusat pada data. Alhasil, digital business diyakini akan menjadi primadona di masa datang. Dengan adanya perubahan tersebut operator diharuskan untuk mampu menemukan kurva pertumbuhan kedua. Menjadidigital telecommunication company pun diyakini menjadi jalan keluar (Selular.id,2018).

Berdasarkan penelitian terdahulu yang dilakukan oleh Eko Harrys mengenai Peran PR dalam pembuatan citra merek mall Central Park, "terdapat pengaruh positif yang signifikan antara peran PR dalam acara Jakarta Great Sale 2010 terhadap citra mall Central Park. Sehingga terjadi hubungan yang kuat antara peran PR dan citra merek" (Jurnal Komunikasi, 2011).

Berikut data perusahaan operator terbesar di Indonesia dalam waktu kurang dari 2 tahun terakhir:

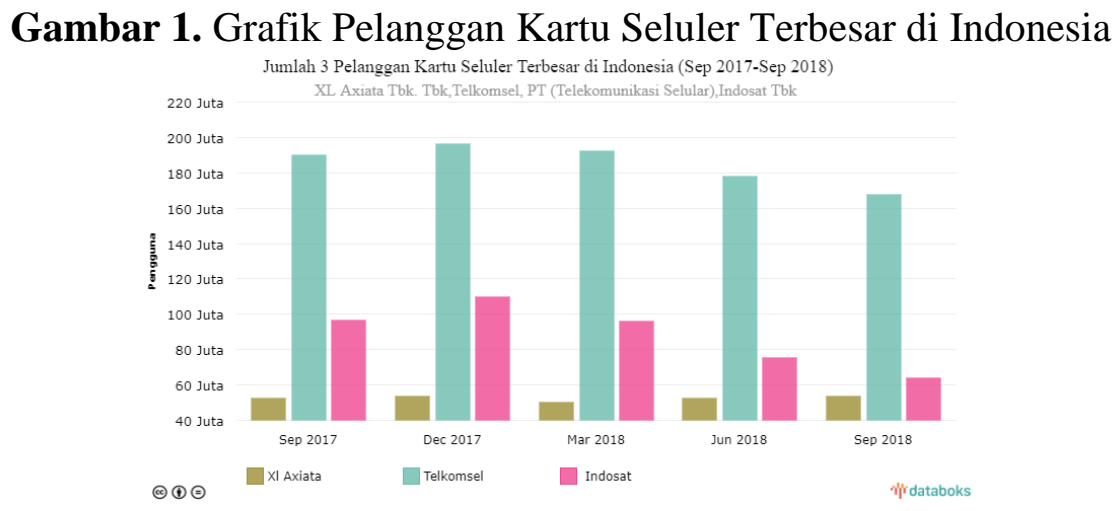

Sumber: Databoks (2018)

Berdasarkan grafik diatas, Telkomsel masih menjadi perusahaan operator no. 1 dengan pengguna terbanyak di Indonesia dengan jumlah pengguna 167,8 juta pada September 2018, diikuti dengan Indosat dengan jumlah pengguna 64,1 juta pengguna pada September 2018. Dalam hal ini, kepuasan konsumen mempunyai peranan yang cukup penting untuk mempertahankan grafik tersebut sehingga pengguna tidak beralih ke operator lain.

Seperti yang diketahui, Telkomsel mendapatkan terpaan isu yang cukup besar dalam beberapa tahun terakhir. Contohnya yaitu persoalan tarif inter-koneksi, PP network sharing dan frekuensi sharing yang direkomendasikan oleh Kemenkominfo, serta peretasan situs resmi Telkomsel dengan kesan tarif yang mahal. Bagi Adita selaku VP Corporate Communication Telkomsel, strategi penanganan isu yang terbilang sangat berat itu pun berbuah manis. Oleh sejumlah lembaga seperti MIX Media, tim PR Telkomsel pernah diganjar penghargaan sebagai Korporat PR Terbaik pada Indonesia PR Program of the Year pada tahun 2013 (Selular.id, 2018).

Dari latar belakang tersebut, penulis ingin mengetahui bagaimana pengaruh peran PR dalam menjaga reputasi perusahaan sehingga penulis mengangkat judul "Pengaruh Peran PR dalam Menjaga Reputasi Perusahaan Telkomsel " 


\section{Metode Penelitian}

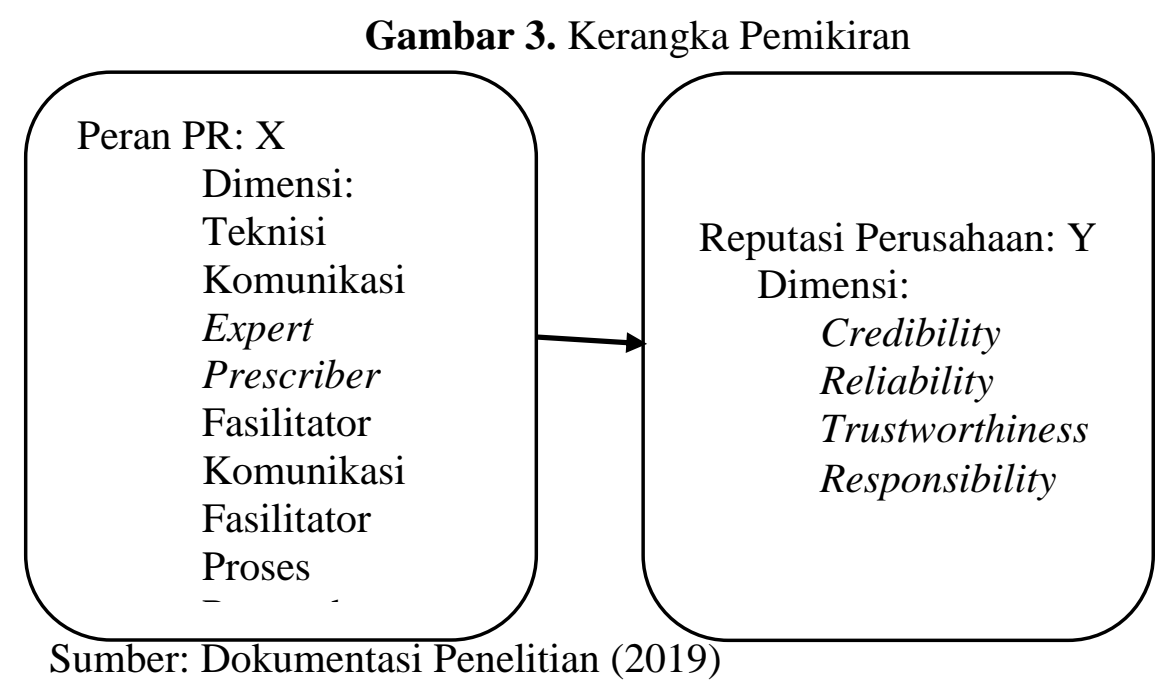

Metode dalam penelitian ini adalah metode kuantitatif dan jenis penelitian survei yang bertujuan untuk mengetahui dan menganalisis pengaruh peran PR yang dilakukan terhadap reputasi perusahaan Telkomsel. Penelitian survei yang dilakukan, peneliti menyebarkan kuesioner kepada pengguna Telkomsel dengan metode simple random sampling. Dari data yang didapatkan, kemudian yang dipelajari merupakan data yang didapatkan dari sampel yang diperoleh dari populasi tersebut. Dari data tersebut didapatkan kejadian yang distribusi, relatif dan hubungan antar variabel, psikologis maupun sosiologis (Sugiyono, 2012). Kuesioner yang disebarkan kepada pengguna Telkomsel via Google Form ini terdiri dari 16 pernyataan yang berhubungan erat dengan dimensi-dimensi dari peran PR dan reputasi. Berikut adalah indikator dari variabel dependen dan independen yang dapat digunakan sebagai pernyataan penelitian:

Tabel 1. Operasionalisasi Konsep Penelitian

\begin{tabular}{|c|c|c|}
\hline Variabel & Dimensi & Indikator \\
\hline \multirow{4}{*}{$\begin{array}{l}\text { Peran PR } \\
\text { (Cutlip, } \\
\text { 2009) }\end{array}$} & Teknisi Komunikasi & $\begin{array}{l}\text { 1. Telkomsel memperbarui konten dari } \\
\text { website telkomsel.com } \\
\text { 2. Telkomsel memiliki hubungan media yang } \\
\text { baik }\end{array}$ \\
\hline & Expert Prescriber & $\begin{array}{l}\text { 1. Telkomsel membantu apabila konsumen } \\
\text { mengalami kendala. } \\
\text { 2. Program yang diberikan Telkomsel } \\
\text { bermanfaat bagi pengguna dan masyarakat. }\end{array}$ \\
\hline & Fasilitator Komunikasi & $\begin{array}{l}\text { 1. Telkomsel memberikan fasilitas bagi } \\
\text { pengguna untuk menyampaikan aspirasi } \\
\text { 2. Pengguna mengetahui layanan dan produk } \\
\text { apa saja yang dimiliki Telkomsel }\end{array}$ \\
\hline & $\begin{array}{l}\text { Fasilitator dalam proses } \\
\text { pemecahan masalah }\end{array}$ & $\begin{array}{l}\text { 1. Telkomsel menyelesaikan kendala yang } \\
\text { dialami pengguna dengan baik } \\
\text { 2. Solusi yang diberikan oleh pihak Telkomsel } \\
\text { sesuai dengan harapan pengguna }\end{array}$ \\
\hline Reputasi & Credibility & $\begin{array}{l}\text { 1. Telkomsel dapat menjaga eksistensi } \\
\text { ditengah persaingan bisnis }\end{array}$ \\
\hline
\end{tabular}




\begin{tabular}{|c|c|c|}
\hline \multirow[t]{4}{*}{$\begin{array}{l}\text { (Fomburn } \\
2016)\end{array}$} & & $\begin{array}{l}\text { 2. Telkomsel stabil dalam memberikan } \\
\text { layanan terbaik kepada konsumen }\end{array}$ \\
\hline & Reliability & $\begin{array}{l}\text { 1. Telkomsel memberikan mutu layanan } \\
\text { sesuai harapan pengguna } \\
\text { 2. Telkomsel memberikan layanan yang } \\
\text { terbaik }\end{array}$ \\
\hline & Trustworthiness & $\begin{array}{l}\text { 1. Pengguna percaya akan keamanan data } \\
\text { pribadi yang dimiliki pihak Telkomsel } \\
\text { 2. Pengguna memiliki rasa kebanggaan } \\
\text { tersendiri saat menjadi pengguna Telkomsel }\end{array}$ \\
\hline & Responsibility & $\begin{array}{l}\text { 1. Telkomsel cepat dalam menghadapi } \\
\text { keluhan pengguna } \\
\text { 2. Telkomsel merupakan perusahaan yang } \\
\text { ramah dan peka terhadap lingkungan sekitar }\end{array}$ \\
\hline
\end{tabular}

Sumber: Dokumentasi Penelitian (2019)

Skala yang digunakan dalam penelitian ini merupakan skala likert yang mengukur sikap, pendapat atau persepsi seseorang tentang fenomena sosial yang mana jawaban dari setiap instrumen pernyataan dari kuesioner penelitian ini memiliki 5 skala likert atau penilaian yakni sangat tidak setuju, tidak setuju, netral, setuju dan sangat setuju. Responden dapat memilih jawaban yang dirasakan paling tepat.

Populasi dari pengguna Telkomsel pada riset terakhir yang dilakukan September 2018 adalah 167.800.000 pengguna (data: databooks 2018). Maka, peneliti menggunakan rumus Slovin untuk mengambil sampel dari penelitian ini. . (Siregar, 2013, p.34)

Dimana :

$$
\mathrm{n}=\frac{N}{1+N e^{2}}
$$

$\mathrm{n}=$ Ukuran Sampel

$\mathrm{N}=$ Ukuran Populasi

$\mathrm{E}=$ Proporsi atau presisi yang diinginkan

$\mathrm{N}$ dan persen ketidaktelitian $\left(\mathrm{e}^{2}\right)$ ditetapkan $10 \%$ dengan tingkat kepercayaan $90 \%$, maka besar sampel yang diinginkan dalam penelitian ini sebagai berikut:

$$
\mathrm{n}=\frac{167.800 .000}{167.800 .000(10 \%)^{2}+1}=\frac{167.800 .000}{167.800 .000(0,01)+1}=\frac{167.800 .000}{1.678 .001}=99,99
$$

Yang dibulatkan menjadi 100 orang.

Peneliti akan mengambil 100 sampel dari database yang diberikan oleh pihak internal Telkomsel dengan tujuan untuk penelitian akademis ini.

\section{Hasil Temuan dan Diskusi}

\section{Karakteristik Responden}

Berdasarkan hasil kuesioner yang disebarkan peneliti kepada responden yakni pengguna Telkomsel, penulis memperoleh data dan karakteristik responden yang terdiri dari jenis kelamin, usia, dan pekerjaan sebagai berikut:

a. Jenis Kelamin : Terdapat 75 orang yang berjenis kelamin laki-laki dan 25 orang yang berjenis kelamin perempuan. Dapat disimpulkan bahwa database random yang penulis terima dari internal Telkomsel mayoritasnya adalah laki-laki. 
b. Usia : Terdapat 2 orang yang berusia dibawah 18 tahun, 57 orang berusia 18-25 tahun, 30 orang berusia 26-36 tahun dan 11 orang berusia diatas 35 tahun. Dapat disimpulkan bahwa mayoritas responden dari penelitian ini adalah pengguna Telkomsel dengan usia produktif.

c. Pekerjaan : Terdapat 4 orang ibu rumah tangga, 55 orang karyawan, 21 pelajar atau mahasiswa, 13 orang wiraswasta dan 7 orang dengan pekerjaan lain.

\section{Uji Validitas}

Pengujian validitas dalam penelitian ini dilakukan dengan menguji penelitian terhadap 100 orang responden yang merupakan pengguna Telkomsel. Pengujian yang dilakukan ini mengambil angka 0,200 sebagai patokan untuk Corrected Item Total Correlation. Berikut adalah hasil uji validitas dari variabel Peran PR (X) dan juga variabel Reputasi (Y).

Tabel 2. Hasil Uji Validitas Variabel X (Peran PR)

\begin{tabular}{|c|c|c|c|}
\hline Item & $\begin{array}{l}\text { Corrected } \\
\text { Correlation } \\
\end{array}$ & $\begin{array}{ll}\text { Item } & \text { Total } \\
\end{array}$ & Keterangan \\
\hline $\mathrm{X} 1$ & 0,530 & & Valid \\
\hline X 2 & 0,702 & & Valid \\
\hline X 3 & 0,659 & & Valid \\
\hline $\mathrm{X} 4$ & 0,653 & & Valid \\
\hline X 5 & 0,742 & & Valid \\
\hline X 6 & 0,694 & & Valid \\
\hline X 7 & 0,690 & & Valid \\
\hline X 8 & 0,597 & & Valid \\
\hline
\end{tabular}

Sumber: Hasil kuesioner yang diolah dengan SPSS (2019)

Tabel 3. Hasil Uji Validitas Variabel Y (Reputasi)

\begin{tabular}{|c|c|c|c|}
\hline Item & $\begin{array}{l}\text { Corrected Item } \\
\text { Correlation }\end{array}$ & Total & Keterangan \\
\hline Y 1 & 0,530 & & Valid \\
\hline Y 2 & 0,229 & & Valid \\
\hline Y 3 & 0,347 & & Valid \\
\hline Y 4 & 0,365 & & Valid \\
\hline Y 5 & 0,394 & & Valid \\
\hline Y 6 & 0,351 & & Valid \\
\hline Y 7 & 0,421 & & Valid \\
\hline Y 8 & 0,597 & & Valid \\
\hline
\end{tabular}

Sumber: Hasil kuesioner yang diolah dengan SPSS (2019)

Dari hasil pengujian indikator variabel peran PR (X) dan reputasi (Y), seluruh hasil memiliki nilai korelasi diatas 0,200 . Dengan demikian, item pernyataan dari variabel $\mathrm{X}$ dan $\mathrm{Y}$ dinyatakan valid.

\section{Uji Reliabilitas}

Uji reliabilitas yang dilakukan dalam penelitian ini menggunakan uji statistik Cronbach's Alpha. Dimensi yang dapat dinyatakan reliabel adalah dimensi yang memiliki nilai Cronbach's Alpha melebihi angka 0,600. Berikut hasil uji reliabilitas dari variabel Peran PR dan Reputasi: 
Tabel 4. Hasil Uji Reliabilitas

\begin{tabular}{llll}
\hline Variabel & N & $\begin{array}{l}\text { Cronbach's } \\
\text { Alpha }\end{array}$ & Keterangan \\
\hline Peran PR (X) & 8 & 0,812 & Reliabel \\
Reputasi (Y) & 8 & 0,805 & Reliabel \\
\hline
\end{tabular}

Sumber: Hasil kuesioner yang diolah dengan SPSS (2019)

Dari hasil diatas dapat diketahui bahwa nilai alpha setelah dilakukan uji reliabilitas yaitu nilai variabel $X$ sebesar 0,812 dan nilai variabel $Y$ sebesar 0,805 . Nilai yang didapati seluruh item lebih besar dari 0,600 . Sehingga dapat dinyatakan bahwa seluruh item reliabel.

\section{Koefisien Korelasi}

Berdasarkan hasil pengolahan data dari program SPSS, nilai koefisien korelasi (R) adalah sebesar 0,808, nilai tersebut menunjukan hubungan antara variabel $\mathrm{X}$ (Peran PR) dan variabel R (Reputasi). Menurut buku Nisfianoor yang terdapat pada tabel 3.3, angka 0,808 menunjukan bahwa terdapat hubungan yang sangat tinggi atau kuat antara variabel peran PR dan reputasi. Hubungan ini bersifat positif yang berarti setiap kenaikan dari variabel X (Peran PR) akan diikuti juga pada kenaikan variabel Y (Reputasi).

\section{Regresi Linear Sederhana}

Pengujian regresi linear sederhana ini digunakan untuk memprediksi nilai suatu variabel independen (X) berdasarkan nilai variabel dependen (Y). Regresi linear sederhana pada penelitian ini bertujuan untuk mengukur pengaruh dari variabel peran PR dan reputasi Telkomsel. Berikut adalah tabel dari hasil olah data regresi linear sederhana:

Tabel 8. Hasil Uji Regresi Linear Sederhana

Sumber: $H$

\begin{tabular}{|r|c|r|r|}
\multicolumn{1}{|c|}{$\begin{array}{c}\text { dized } \\
\text { nts }\end{array}$} & $\begin{array}{c}\text { Standardized } \\
\text { Coefficients }\end{array}$ & \multicolumn{1}{|c|}{} \\
\cline { 1 - 2 } Std. Error & Beta & \multicolumn{1}{c|}{$\mathrm{t}$} & \multicolumn{1}{c|}{ Sig. } \\
\hline 1,792 & & 3,393 &, 001 \\
, 060 &, 808 & 13,561 &, 000 \\
\hline
\end{tabular}

Berdasarkan tabel (hasil uji t) maka didapatkan sebuah model persamaan regresi linear sederhana sebagai berikut:

\section{$Y=6,081+0,808 X$}

Hasil yang didapatkan di atas memberikan kesimpulan bahwa jika pengaruh yang diberikan oleh peran PR terhadap reputasi Telkomsel sebesar 0 , maka nilai reputasi Telkomsel adalah 6,081. Sedangkan apabila pengaruh yang diberikan oleh variabel peran PR terhadap reputasi perusahaan adalah sebesar 1, maka nilai reputasi perusahaan akan mengalami peningkatan koefisien sebesar 0,808. Koefisien bernilai positif yang berarti terjadi hubungan yang positif antara peran PR terhadap reputasi Telkomsel. Semakin besar peran PR yang dilakukan akan semakin meningkatkan reputasi Telkomsel. 


\section{Uji Hipotesis} berikut:

Hasil analisis regresi antara Peran terhadap Reputasi dapat dilihat dari tabel

Tabel 9. Hasil Uji Hubungan (t)

\begin{tabular}{|c|c|c|c|c|c|c|}
\hline \multicolumn{7}{|c|}{ Coefficients $^{a}$} \\
\hline \multirow[b]{2}{*}{ Model } & & \multicolumn{2}{|c|}{$\begin{array}{l}\text { Unstandardized } \\
\text { Coefficients }\end{array}$} & \multirow{2}{*}{$\begin{array}{c}\begin{array}{c}\text { Standardized } \\
\text { Coefficients }\end{array} \\
\text { Beta }\end{array}$} & \multirow[b]{2}{*}{$t$} & \multirow[b]{2}{*}{ Sig. } \\
\hline & & B & Std. Error & & & \\
\hline & (Constant) & 6,081 & 1,792 & & 3,393 &, 001 \\
\hline & Peran PR & , 808 &, 060 & 808 & 13,561 &, 000 \\
\hline
\end{tabular}

Sumber: Hasil Pengolahan Data Penelitian dengan SPSS

Adapun uraian mengenai hipotesisnya adalah sebagai berikut:

a. Ho : Tidak terdapat pengaruh yang signifikan antara peran PR terhadap reputasi Telkomsel

b. Ha : Terdapat pengaruh yang signifikan antara peran PR terhadap reputasi Telkomsel

Berdasarkan hasil dari tabel 4.24, dapat diketahui signifikansi pada pengaruh Peran PR terhadap Reputasi adalah 0,000 yang berarti pengaruh antara Peran PR terhadap Reputasi telah tersignifikan atau jelas. Sehingga dapat disimpulkan bahwa Ho ditolak dan Ha diterima yang berarti adanya pengaruh yang signifikan antara peran PR terhadap reputasi perusahaan Telkomsel.

\section{Simpulan}

Dari hasil penelitian yang telah dilakukan, peneliti dapat menyimpulkan bahwa terdapat pengaruh antara Peran PR terhadap reputasi perusahaan Telkomsel 65,2\%. Sisanya yaitu $34,8 \%$ dipengaruhi oleh faktor lainnya. Dari hasil linear sederhana, didapatkan persamaan $\mathrm{Y}=6,081+0,808 \mathrm{X}$. Jika pengaruh yang diberikan oleh variabel Peran PR terhadap reputasi perusahaan sebesar 0, maka nilai reputasi Telkomsel adalah 6,081. Sedangkan apabila pengaruh yang diberikan oleh variabel peran PR terhadap reputasi perusahaan adalah sebesar 1, maka nilai reputasi perusahaan akan mengalami peningkatan koefisien sebesar 0,808 . Dengan demikian dapat disimpulkan bahwa terjadi hubungan yang positif antara peran PR terhadap reputasi Telkomsel. Semakin besar peran PR yang dilakukan akan semakin meningkatkan reputasi Telkomsel. Dari hasil uji hipotesis atau uji penelitian ini, yang didapatkan dari hasil signifikan 0,000, kurang dari 0,05 yang dapat dikatakan bahwa Ho ditolak dan Ha diterima. Dapat dikatakan terdapat pengaruh yang signifikan antara variabel Peran PR terhadap reputasi perusahaan Telkomsel.

\section{Ucapan Terima Kasih}

Peneliti mengucapkan terima kasih kepada seluruh pihak yang telah membatu penelitian ini. 


\section{Daftar Pustaka}

Cutlip, Scoot M., Allen H. Center, dan Glen M. Broom. (2009). Effective Public Relations. Edisi Kesembilan. Jakarta : Kencana Cetakan ke 3.

Databoks (2018) Operator Seluler Terbesar di Indonesia. 10 September 2019. https://databoks.katadata.co.id/datapublish/2018/11/19/wajib-registrasipelanggan-seluler-indosat-menyusut-34

Fombrun dalam Ardianto, Elvinaro. (2016). Metodologi Penelitian untuk Public Relations Kuantitatif dan Kualitatif. Bandung : Simbiosa

Reska K. Nistanto. (2017 April, 28) Begini Kronologi Peretasan Situs Menurut Dirut $\begin{array}{lllll}\text { Telkomsel. } & 19 & \text { November } & 2019 . & \text { Kompas }\end{array}$ https://tekno.kompas.com/read/2017/04/28/18471727/begini.kronologi.pereta san.situs.menurut.dirut.telkomsel)

Siregar, Syofian. (2013) Metode Penelititan Kuantitatif. Jakarta : PT. Fajar Interpratama Mandiri

Sugiyono (2012) Metode Penelitian Kuantitatif dan Kualitatif dan R\&D. Bandung : Alfabeta

Susanto, Eko Harry. (2011) Peran PR dalam Pembuatan Citra Merek Mall. Jurnal Komunikasi. Vol 3. No. 2. 